\title{
Sign and Its Significance in John's Gospel
}

\author{
Warseto Freddy Sihombing, ${ }^{1 *}$ Iwan Setiawan Tarigan ${ }^{2}$ \\ Institut Agama Kristen Negeri Tarutung, Indonesia \\ *email: asafremel@gmail.com
}

\begin{abstract}
John uses the term "sign" in his Gospel to describe particular miracles that Jesus performs in His ministry as evidence of His divinity and sign posts to receive eternal life from God. By using an historically and theologically oriented hermeneutical method as a part of qualitative research, this article provides an interpretation of the seven signs in Gospel of John as authentic evidence of the main work of Jesus during His ministry on earth: namely, the revelation of Jesus' divinity and consequent demands on people's lives, like responding to his claim as Savior. John deliberately chose the seven signs or miracles that Jesus performed. The significance of those signs reveals the glory of God within Jesus to a sinful world, so that those who see and know them will believe in Jesus Christ and receive the eternal life.
\end{abstract}

Key Words: sign, believe, significance, Jesus Christ, Gospel of John

Article History:

Submitted: April 24, 2021

Revised: Jan. 24, 2022

This is an open access article under the CC BY-SA license (c) (i) (2)
Published: Jan. 29, 2022

\section{INTRODUCTION}

This article is motivated by an interest in one of the differences in John's description of the miraculous deeds that Jesus performed during His ministry. In the Synoptic Gospels the ministry that Jesus performed while healing the sick and performing other miraculous deeds is described by the authors as "miracles," while in the Gospel of John, he prefers to use the term "sign" (Carson et al., 2002).

In addition, the lack of discussion of the signs in the Gospel of John in Indonesian journals is the reason for this further research. From the author's findings, there are several discussions related to the Gospel of John: first, by Gratiana Tafaib (2014) in an article entitled Understanding Eschatology in the Gospel of John and Its Temporal Meaning, where she discusses John's eschatology, which places the idea of salvation and divine judgment in the category of "present time." According to her, there is an eschatological problem in John's understanding (Tafaib, 2014). In a second article entitled Jesus Is the Bread of Life: Narrative
Analysis of John 6:1-71, the author, Joihin, hopes that readers can truly understand the meaning of Jesus who is the Bread of Life in contemporary life today (Joihin, 2010). In a third article entitled Interpreting the Religious Symbols of the Gospel of John, Petrus Lakonawa explores the hermeneutic approach in finding symbolic meanings in the Gospel of John (Lakonawa, 2014). There are two other articles; one written by Darmadi (2019) entitled Understanding John's Theology of the End Times, and the second Methods of Evangelizing: Jesus in the Gospel of John 4:1-42 (Harming, 2017).

The author chose this title to focus on the "sign" performed by Jesus and its significance in the Gospel of John as a public affirmation of His divinity and a challenge to trust Him to gain eternal life. In chapters 1:19-12:50 John describes the signs Jesus performed, and in chapters 20:30-31 it becomes clear that from 'John's perspective', his entire Gospel is "a book of signs" (Carson et al., 2002).

Realizing that humans are sinners and do not have the ability to escape God's judgment only makes humans inevitably have to depend on God's 
grace to obtain eternal life. Faith in Jesus Christ is the only way for mankind to be saved (John 3:16; 14:6). No one comes to the Father except through Jesus Christ, the Son of God. This means that no one has eternal life unless he has faith and abides in Jesus Christ, the Son of the living God, who has revealed who God really is (John 1:14, 18). The discussion of signs in John's Gospel is part of the depth of John's Christology, and everything that talks about Christianity must be centered on Christ (Simanjuntak, 2019, pp. 75-86). Although not a few people have obscured the substance of Christ as God (Simanjuntak, 2019, p.77), which can be seen from the rejection of the divinity of Jesus Christ, the signs that Jesus has performed narratively in John's gospel confirm that Jesus Christ is God.

Several important questions are asked regarding the signs that Jesus performed and their significance in the Gospel of John. What signs did Jesus perform as part of his public ministry? Is an event explicitly identified as a "sign" in John's Gospel? Can this event, which is symbolic, refer to the glory of God that Jesus displayed on earth? This research aims to answer those questions.

\section{METHOD}

The method used in this research is the historical-theological hermeneutical method which is part of qualitative research (Subagyo, 2004) the interpretation of each sign performed by Jesus in the Gospel of John. As the purpose of using a hermeneutic approach on the data is to gain a better understanding of the context that gives meaning (Subagyo, 2004), this study focused on the signs in the Gospel of John that directly point to the person of Jesus, where John is present as an eyewitness (Bauckham, 2017). The ultimate goal of every sign that Jesus performed was to declare His divinity publicly and challenge his listeners to believe in Him. In the end, there is an increasing significance of every sign Jesus performed, from the first: turning water into wine, to the last: raising Lazarus from the dead. In this study, it is emphasized that every sign performed by Jesus has a special significance, which culminates in a clearer picture of who Jesus is.

The sign that was performed by Jesus is an historical event and at the same time has a theological meaning. The hermeneutical approach by an eyewitness, in this case the apostle John, to every sign performed by Jesus resulted in a conclusion that Jesus is God's final and perfect revelation to the world. This analytical method is seen in the following diagram:

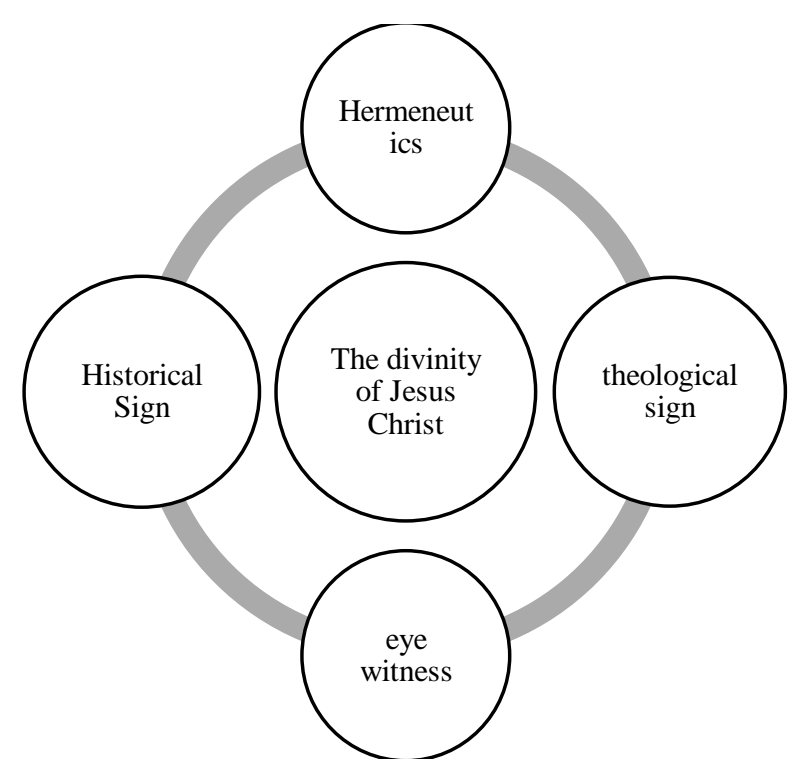

Chart 1. Historical-Theological Analysis Method

\section{RESULTS AND DISCUSSION}

There are three main discussions in this study in relation to the seven signs and their significance in the Gospel of John, namely: Key Terms, Purpose of Signs, and Significance of Signs.

\section{Key Terms: Sign, Believe and Live}

There are many prominent terms in John's Gospel, but three of them are the most emphasized and repeated: sign, believe, and live. These three terms are the main keys that are interrelated with each other in understanding John's theological thinking in his gospel. The first term, "signs," refers to the structure of the Gospel of John, especially the first part: chapters $1-12$. The seven signs which must also be interpreted the same as miracles, were performed by Jesus in public to meet the needs of others. Jesus' ability to perform all these signs has 
significance for the divinity of Jesus (Keener, 2012). The signs point to the divinity of Jesus which is John's main goal in his prologue (1:1-18). The power that Jesus showed was not to show off in front of people, but rather to fulfill the task that Jesus had from His Father.

John said: "No one has ever seen God, but the one and only Son, who is himself God and is in closest relationship with the Father, has made him known" (1:18). Many scholars think that this verse describes Exodus 33:20 (Keener, 2012). Moses, although performing many miraculous signs from God as evidence of God's presence, was not God's final or perfect revelation to humanity. In contrast to Moses, Jesus made 'God known' beyond just his "backside" as He revealed Himself to Moses (Ex 33:18-23). Jesus manifests the Father's full and perfect presence (Keener, 2012, p. 422-423). Now, the Son reveals the God (Father) who has been with him since eternity (Brown, 1988). Jesus is the Word who was with God from the beginning. The signs that were performed by Jesus revealed in no uncertain way that $\mathrm{He}$ was God.

Why did John prefer the term "sign" in describing those seven particular miracles of Jesus?

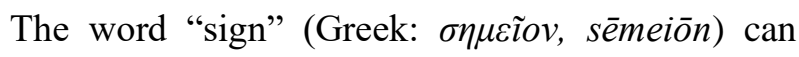
mean: (1) A sign or distinction; (2) An event that indicates or intervenes by divine power, miracles, and signs that only God and Jesus can perform (Arndt et al., 2001). In the Gospel of John, these two meanings are included. The two main purposes of John's use of the word signs are: 1) To express the authenticity of Jesus' ministry - to reveal His glory; and 2) To convince people to believe in Jesus Christ.

The second term, "believe" is another major keyword to understand the Gospel of John. It is closely related to the previous term. Believing in John means the awareness of someone who because he has seen and knows all that Jesus did...dares to decide to entrust his life to Jesus (Morris, 2014, p. 381-382). This word contains the whole meaning of Christianity. According to 1:12, "Yet to all who did receive him, to those who believed in his name, he gave the right to become children of God.” In 3:16
John writes in a narrative aside: "For God so loved the world that he gave his one and only Son, that whoever believes in him shall not perish but have eternal life." There is a close relationship between believing in the name of Jesus and eternal life, where the name of Jesus has divine power (Schreiner, 2015). Christ becomes the only eternal alternative to the world (Schreiner, 2015). It is not because the world is good that God is attracted to it, but that God has revealed His love through Christ. The language of John here is more qualitative than quantitative (Keener, 2012). God loves the world very much and gives eternal life through Christ's work on the cross, which is the culmination of the expression of God's great love.

In these two verses, there is a nonnegotiable and irresistible affirmation of 'cause and effect' for those who believe in Jesus. The power or the right to become children of God will only be obtained by those who are willing to accept Jesusacknowledging Him as the God who has been incarnated into man and perfectly expresses God's love for sinful humans. Likewise, 'eternal life is only obtained by those who want to believe-accept the work of Jesus as the only gift from God the Father to sinners, which is evidenced in all the actions and works that Jesus did-His suffering, death and resurrection are the culmination of salvation history. God has not only spoken but also acted (Schreiner, 2015).

To believe or not believe (rejection of Jesus directly or indirectly) is often aligned as the polarization of John's narrative in his Gospel (Harris, 2011, p. 235). There are consequences depending on the response of people who meet Jesus. Jesus' most emphatic statement about this is found in His conversation with Nicodemus. In a narrative aside John writes: "He who believes in Him is not judged; he who does not believe has been judged already because he has not believed in the name of the only begotten Son of God" (3:18). Likewise, "Whoever believes in the Son has eternal life, but whoever rejects the Son will not see life, for God's wrath remains on them." (3:36). 
There is a contrast between believing and rejecting the Son (same as unbelief) in that verse (Harris, 2011, p. 236). The same affirmation is also found in chapter 5 when Jesus spoke to the Jewish leaders who hated Him. Jesus said to them:

You study the Scriptures diligently because you think that in them you have eternal life. These are the very Scriptures that testify about me, yet you refuse to come to me to have life... But since you do not believe what he wrote, how are you going to believe what I say? (5:3947).

Jesus knew very well what the Pharisees and scribes were like. In this passage it is explained that after Jesus testified of Himself as the divine Son of God, Jesus pointed to four witnesses that were wellknown by the Jews: first, John the Baptist; second, the work that Jesus did-signs; third, God the Father himself; and fourth, the Book of Moses (Brown, 1988). But even though there were so many witnesses (more than two), they still didn't want to believe in Jesus. John describes the personality of the Pharisees and Scribes: they did not actually love God because they only expected praise from men (Brown, 1988). As a result, the Scriptures (the law of Moses) became the judge of their unbelief, because who they were dealing with was even greater than Moses.

Jesus concluded that the Jewish leaders (representing other Jews at the time of Jesus) had rejected both the testimony of Scripture (Moses) and the testimony of Jesus himself. Later in chapter 6 , the teaching of Jesus after feeding 5000 people, this polarization of belief and rejection reappears. One notices in this section how tense the situation was at that time. The up and down rhythm of this conversation adorns Jesus' claim to be the Bread that came down from heaven to rebuke their unbelief. The Jews wanted to do the work that God wanted. And Jesus' answer was an invitation to believe in Him. The Jews even doubted Jesus by demanding a sign that Jesus could show, when they compared Jesus with Moses. Jesus asserted that it was not Moses who gave the bread from heaven to their ancestors, but God; and that the bread from
God was the bread that came down from heaven and gave life to the world - that very-same bread was Jesus himself. Jesus himself was a sign they could witness, greater than any sign that their ancestors, the Israelites, had ever witnessed. But even though they had seen Jesus, they still did not believe (6:36).

Regarding the third major key term, "live" is a summary of everything that is given to those who will believe in the atoning work of Jesus Christ. Eternal life is 'when people have known the Father, the only true God, and have known Jesus Christ, as (the only) messenger of the Father' (17:3). The life that Jesus meant was not just physical existence, but also involved a new awareness, the nature of life itself, and its continuous reciprocal relationships (Tenney, 2010, p. 237). Jesus Christ has offered that life to humans and the life offered is Christ himself (Kok, 2015).

The life that was offered by Jesus in this fourth gospel is the realization of divine communication and God's plan as the central concept in the prologue of the Gospel of John in chapters 1:1-18 (Zuiddam, 2016). By philological analysis of the passage of the text, he finds that the concept of logos has its roots in the Old Testament and John conveys it in the form of a Greco-Roman cultural parallelism setting (Zuiddam, 2016).

Thus, these three important key terms: sign, believe, and live, give a logical structure to the Gospel of John (Tenney, 2010, p. 238). With the terms "sign," there is a revelation of God's glory through Jesus; with "believe", there is a reaction or response that is expected; and with "life", there are significant benefits that accrue to those who believe.

\section{The Purpose of Sign}

When reading the seven signs in the Gospel of John, the reader will be led to John's main goal, which is to become a Christian, by believing and knowing Jesus who is the perfect revelation of God. The Gospel of John is the most distinct and perhaps the most valuable account of the four canonical gospels (Tenney, 2010, p. 232). 
The teachings of Jesus contained in the Gospel of John are more about His personal than the ethical teachings about the Kingdom of God. He recorded many personal conversations in his Gospels and emphasized the importance of having a personal relationship with Jesus (Tenney, 2010, p. 232). The content of His gospel is more theological in discussing the divinity of Jesus Christ and demanding faith in Jesus from its readers.

Basically, the purpose of John writing his Gospel, in general, has the same main emphasis as the Synoptic Gospels: to introduce Jesus as God to the readers and the world (Köstenberger, 2015). However, different results will be seen when studying each gospel. The Gospel of John provides a deep insightful picture of who Jesus Christ is for two main reasons. First, John wants readers and people who have believed in Jesus Christ to have spiritual depth regarding knowing who Jesus Christ really is and what God wants for people who have accepted and believed in Jesus (Morris, 2014). Second, John made his gospel a message/mission delivered to Jews and Gentiles who had not yet acknowledged Jesus as the Messiah, the Son of the living God, the Messiah who had come, who was promised by God beforehand (Carson, 1991).

In both of these lie the main purpose of the Gospel of John. John knew who Jesus really was, starting when he became one of His disciples, following $\mathrm{Him}$ wherever $\mathrm{He}$ went to serve, witnessing to what Jesus was doing, and being involved in every aspect of Jesus' ministry (1 John 1:1-3). Whatsmore, John had been a faithful servant until the time his Gospel was written (until his death). John personally had a deep knowledge of Jesus, not just speculating that Jesus was the Messiah, the Son of the living God. Jesus' oneness with the Father is unique and is consistently found in the Gospel of John, which has been understood and lived by John. John wanted "everyone to believe and be a follower of Jesus Christ" (Darmadi, 2019, pp. 21-33).

It must be admitted that the term "the

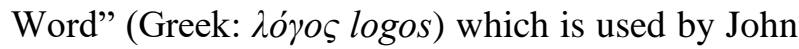

often leads readers to the idea that John was heavily influenced by gnostic thought (Arndt et al., 2001). But that is not true, for several reasons. Irenaeus, an early church father believed and said that John was a disciple of Jesus who had published the Gospel in Ephesus and lived in that city until the time of Trajan (Guthrie, 2012, p. 234). In fact, Tertullian, Clement from Alexandria, and Origen supported Irenaeus' view, when he used the Gospel of John to refute Gnostic teachings in the second century AD. Furthermore, this Gospel of John was accepted into the canon of the early church, once for all (Köstenberger, 2015, p. 23). And because of that, there is no doubt that the early church believed and worshiped Jesus as God. Other church fathers also firmly identified this gospel with John, who is called "the beloved disciple" in John 13:23 and in their other writings in the early church (Köstenberger, 2015, p. 23).

In fact, the traditional acceptance of John's writings is older than Irenaeus' time, because John was an eyewitness to all that was told in his Gospel (Keener, 1993). He was the disciple who knew Jesus very closely; it was he who leaned close to Jesus at the Last Supper (13:23). In John 21:24 it is recorded that "John was the disciple, who testified to all that Jesus had done, and his testimony is true" (Blum, 2010).

Signs performed by Jesus in the Gospel of John such as turning water into wine at a feast at Cana (2:1-11) and others are stories that are not found in the Synoptic Gospels. This is evidence that John was present at that time as an eyewitness to Jesus' ministry on earth. As in John 18:15, the phrase "another disciple" placed after Simon Peter's name when they followed Jesus into the courtyard of the High Priest's palace, refers to John (Blum, 2010). So, there is no doubt that the purpose of the Gospel of John is to reveal the divinity of Jesus Christ as proven in all the signs He performed during His earthly ministry.

\section{Sign Identification}

The seven signs in the Gospel of John are: 
1. Turning water into wine at the wedding at Cana (John 2:1-11)

2. Clearing the Temple Courts (John 2:13-25)

3. Healing an Official's Son (John 4:46-54)

4. Healing the sick at the pool of Bethesda (John 5:1-15)

5. Feeding the crowds (John 6:1-15)

6. Healing a man born blind (John 9)

7. Raising Lazarus from the Dead (John 11)

In his Gospel, John does not mention that the list of the seven signs performed by Jesus are "miracles," such as are found in the Synoptic Gospels. This is a major feature that makes his Gospel unique (Constable, 2020). Of course, John had his reasons for using the term sign instead of miracle. As discussed in the previous section, the term "sign" is used in reference to Jesus showing his glory of as the true representative of God (John 20: 30-31). These signs can be further evaluated: 1) What signs did Jesus perform as part of his public ministry? 2) Is an event explicitly identified as a "sign" in John's Gospel? and 3) can the event, which is symbolic, refer to the glory of God shown by Jesus, and proclaim that Jesus is the true representative of God on earth?

Each of the signs performed by Jesus in the Gospel of John can be identified as follows: First, the seven signs performed by Jesus that appear in chapters 1-12 of the Gospel of John relate to Jesus' mission to the Jews. The statement in chapter 12:37 which states that "Even after Jesus had performed so many signs in their presence, they still would not believe in him," effectively closing the first part of his Gospel, is the final reference to "signs." to achieve the ultimate goal: believing that Jesus is the Messiah, the Son of God (20:30-31). It is understandable why John chose the seven signs as a demonstration of Jesus' Messiahship - the fulfillment of the Old Testament (Constable, 2020).

Second, it appears that every sign identified somewhere in John's Gospel (often somewhat indirectly) points to the person of Jesus. The seven signs or miracles that Jesus performed were recorded by John for a single purpose, namely: “[so] that you may believe that Jesus is the Messiah, the Son of God and that by believing you may have life in his name." Each of these signs is explained in further detail in John's Gospel after the event from which each sign supports John's overall purpose, as recorded in the 20:31. The chart below summarizes the relationships between the things marked by each of the seven signs in John's Gospel.

\begin{tabular}{ll}
\hline \multicolumn{1}{c}{ Signs } & \multicolumn{1}{c}{ The meanings } \\
\hline $\begin{array}{l}\text { Turning water into wine at the } \\
\text { wedding at Cana (2:1-11) }\end{array}$ & $\begin{array}{l}\text { Jesus is the Messiah who inaugurated the new covenant order and } \\
\text { brought abundant joy to life. }\end{array}$ \\
\hline $\begin{array}{l}\text { Clearing the Temple Courts (2:13- } \\
\text { 25) }\end{array}$ & $\begin{array}{l}\text { Jesus is the new temple of God, where His resurrection proves that } \\
\text { He is not defeated even by death. }\end{array}$ \\
\hline Healing an Official's Son (4:46-54) & Jesus is the Son of God who gives life with the word of his strength. \\
\hline Healing the sick at the pool of & $\begin{array}{l}\text { Jesus is the Son of God who made man whole physically and } \\
\text { spiritually. }\end{array}$ \\
\hline Bethesda (5:1-15) & $\begin{array}{l}\text { Jesus is the bread of life that gives eternal life to those who believe } \\
\text { and will endure through eternity. }\end{array}$ \\
\hline Healing a man born blind (9) & $\begin{array}{l}\text { Jesus is the light of the world who gives sight to the blind- } \\
\text { spiritually. }\end{array}$ \\
\hline Raising Lazarus from the Dead (11) & $\begin{array}{l}\text { Jesus is the Resurrection and the Life, who has power over death and } \\
\text { gives life to the dead physically and spiritually. }\end{array}$ \\
\hline & Table 1. Signs \& The Meanings
\end{tabular}


Synchronically, there are levels of significance from the first sign to the seventh sign. The culmination of the signs that Jesus performed which ends in chapter 11 is about raising Lazarus, after which John's focus continues on the fulfillment of the sign's significance to Himself, culminating in the Jewish agreement to crucify Jesus.

The signs that Jesus performed play an important role in the argument, theology, and structure of John's Gospel (Stibbe, 2001). The plot development in John's Gospel is progressively seen in the repetition of signs, metaphors, symbols, and teachings to confirm the identity of Jesus as divine (Stibbe, 2001). The end of the Gospel of John is a challenge to the recipients and readers of this Gospel: "Jesus performed many other signs in the presence of his disciples, which are not recorded in this book. But these are written that you may believe that Jesus is the Messiah, the Son of God and that by believing you may have life in his name." John emphasized that the sign that Jesus did and its significance had an impact on strengthening and awakening the faith of readers and recipients as well as an evangelistic tool to invite believers to Jesus as the Messiah, the Son of God to have eternal life (Köstenberger, 2015).

There are 3 important things that can be known and can be a guide in identifying the signs and understanding their significance in the Gospel of John. First, the Gospel of John does not contain all the historiography about Jesus, but contains what is sufficient to know and respond to the challenge of Jesus. John deliberately chooses what the reader really needs to know who Jesus really is. Second, the main mission of the Gospel of John is to reach as many people as possible (especially Jews) to believe in Jesus Christ, the Messiah, the Son of God (Wenham, 2003). But John didn't want to reach only Jews, but Gentiles too. Third, faith in Jesus Christ, the Messiah, the Son of God will bring life in His name to those who believe and accept Him. Lastly, of course, John refers to eternal life which is given by God only through Jesus Christ, His Son to those who believe (John 3:16). He consistently uses the term 'sign' from the beginning to the end of his writings.

\section{Significance of Signs for Believers}

Every sign that Jesus did has significance to Himself for those who believe. The significance of the seven signs that Jesus has done in the Gospel of John for Christians/believers are:

\section{Believe and Know Jesus}

The seven signs that John has described in his Gospel are actually enough to make people believe in Jesus. How should those who see and know the sign respond to Him? God, through Jesus Christ, has given (offered) to every believer salvation, referred to as eternal life in John's Gospel. This salvation is a guarantee from God for reconciliation in the present life and eternal life in the future. The seven signs in John's Gospel are authentic evidence of Jesus' main work in His ministry on earth to introduce Himself to the world to 'believe' and 'receive' salvation from God. God has sent Jesus Christ to reveal God's great love for sinners. Jacobus Kok states that the missionary idea in John's Gospel is a Leitmotiv (central or dominant theme) that integrates Christology and Soteriology in the fourth Gospel (Kok, 2015). On the one hand, the sign that Jesus did was the work that God the Father had entrusted to Him. On the other hand, as in an interesting topic Aspects of Irony in the Johannine Narration described by Paul N. Anderson, the people and the Jewish leaders did not believe in Jesus because they misunderstood the mission of Jesus. This is "an irony." The significance of every sign Jesus did was a revelation of His divinity (Reinhartz, 1999). They, the Jews in general, have rejected the divine sign that Jesus had done and demanded another sign of Jesus to be done, and this is a sad irony (Reinhartz, 1999). For believers living today, the Jewish rejection of Jesus is a serious warning also in terms of faith in Jesus. Those who have seen and know the sign that Jesus performed at that time gave a response of refusal to believe in Him. As the consequence, God's 
judgment will be revealed in His time for rejecting the revelation of His Son. Therefore, for believers today, rejecting the divinity of Jesus is the same as not wanting to accept the grace that God the Father has revealed through Jesus Christ, His Son.

The signs that Jesus did have revealed God's glory in the midst of a sinful world. Jesus is the Servant who has been prophesied by Isaiah in Isaiah 42:1-4, serving humbly, not carrying out His own program, but what God has entrusted to Him (Sihombing et al., 2021). God wants every person to see, know, and believe in his Son through recorded signs. This must continue until the "believer wants to know Jesus more deeply," just as John's testimony, based on his deep knowledge of Jesus Christ, introduced Jesus to both Jews and Gentiles (Sihombing et al., 2021). John helps the reader to see and 'experience' Jesus, and thus also to see and 'experience' God (Merwe, 2019). It is undeniable that when reading the Gospel of John, the impact is that the reader enters into a closer knowledge of Jesus. The reader is brought in to experience imaginatively what happened with Jesus in the text so that what happened in the Gospel of John becomes an experience in the present (Merwe, 2019).

There is another unique elements found in the Gospel of John in relation to believing and knowing Jesus, namely the 'questions' of Jesus. The Gospel of John records many of Jesus' questions in each of its narratives and some of them appear when the sign is done by Jesus $(1: 38,50 ; 3: 10,12 ; 5: 6,44$, 47; 6:61, 62, 70; 7:19; 8:10, 25, 43, 46; 9:35; 10:32; $11: 26,40 ; 13: 12,38 ; 14: 9,10 ; 16: 19,31 ; 18: 4,7$, $11,21,23,34 ; 20: 15,29 ; 21: 15,16,17$ ) (Estes, 2013). This is unusual and certainly John has a purpose in arranging his narrative in such a way. Almost all of Jesus' questions in John's Gospel are part of John's discourse persuasive scheme (Estes, 2013). Every question Jesus asks challenges readers to ask themselves who Jesus really is. It appears that John as the narrator has the main purpose of his gospel so that the reader understands and can make a decision to believe and accept Jesus (20:31). As a follow-up to believing and knowing Jesus more deeply, this is a desire to introduce Jesus to people just as John did by writing his Gospel.

\section{Proclaiming the Glory of Jesus}

The second significance of each sign brings the reader fully to the pinnacle of the purpose of the signs in the Old Testament. Just like the signs in the Old Testament, the signs in the Gospel of John also serve to authenticate the divine Messianic ministry and the message of the gospel of Jesus Christ in comparative language (Merwe, 2019). For example, Moses, who was God's mediator for the Old Covenant, showed signs to the Israelites as evidence of God's presence in the midst of His people. Moses acted as God's representative who proved God's power was in the midst of the Israelites. There were many signs and miracles that Moses performed, both in front of the Israelites and in front of Pharaoh and the Egyptians from the beginning of his call to the day he died on Mount Nebo. None of the signs and miracles done by Moses was intended to glorify himself, but rather an invitation to believe in the Lord God who sent Moses. Moses, in this case, became God's representative (in the Old Testament) on earth to introduce who $\mathrm{He}$ was and what $\mathrm{He}$ could do on earth. (Tarigan, 2019).

Likewise, Jesus was also a mediator - but of a new, better, and permanent covenant, He was the promised prophet like Moses but surpassed Moses in all glory and majesty (Deut. 18:18) to reveal the true God. In a way, Jesus is the same as Moses, as God's representative on earth. In another sense, Jesus is superior to Moses, because Jesus is the final revelation of God (John 1:17-18). Jesus' statement in front of the crowd "I am," stated that He is God who has revealed Himself in the flesh. In this verse's clear antithetical parallelism, John contrasts Jesus with Moses. Jesus is the eschatological fulfillment of everything Moses ever did (Ex. 33:15-16; 34:9) (Merwe, 2019). Through these signs, Jesus' claim to be the Son of God is true. Jesus used signs to prove the authenticity of His ministry and to reveal His glory. The sign itself is a work that God has entrusted to Him, so that whoever 
has seen and knows Jesus is the same as having seen and known God (Schreiner, 2015). In this case the glory of Jesus is revealed and at the same time challenges everyone who sees and knows Him to respond. His resurrection and ascension to heaven is the culmination of the revelation of the glory of Jesus.

When Jesus performed these signs, $\mathrm{He}$ consistently directed people not to focus only on the sign but on what the sign signified. In Cana, Galilee, where He turned water into wine, the point was not to enjoy a glass of fine wine but to see Jesus as the promised Messiah - the One who brought joy and who would host His own wedding banquet with His bride. Jesus used these signs to show who He really was, what He had accomplished, and to show people that they really needed him as a personal Savior. Therefore, each of the seven signs serves to signify something about the reality of who Jesus was and what to do.

\section{Christian Apologetics in Convincing People to Believe in Jesus Christ}

The first coming of Jesus was to reveal who Jesus is to the world: God who has revealed Himself in the person of Jesus Christ. Many of the Jews rejected Him, as well as the Romans who tended to view Jesus as more or less a troublemaker (Evans, 2007). Starting from the first coming of Jesus, in the early days of the church and until now (especially for pluralists) the divinity of Jesus has always been ruled out (Oet, 2016). Disbelief that Jesus is God will lead a person to the conclusion that Jesus was just a human being like everyone else. On the other hand, the beginning of the opening of the Gospel of John has stated the divinity of Jesus (1:1-18), followed by the signs that $\mathrm{He}$ did confirm and prove the divinity of Jesus (Oet, 2016).

The seven signs in the Gospel of John are closely related to the field of Christian apologetics. The signs that Jesus did, had a persuasive purpose, which John explicitly acknowledged towards the end of his gospel. In chapter 20, John reveals to his readers that he deliberately chose many signs:
"Jesus performed many other signs in the presence of his disciples, which are not recorded in this book. But these are written that you may believe that Jesus is the Messiah, the Son of God and that by believing you may have life in his name" (John 20:30-31). John noted that Jesus in his ministry also performed evangelism, such as to Samaritan women, through a cross-cultural (multicultural) and contextual approach (Harming, 2017). It can be seen as a whole that the Gospel of John is an apologetic tool used by John to invite others to believe in Jesus.

Jesus performed these seven signs during His public ministry. He associates the sign with His identity, and John is making a similar connection with all those who read his Gospel today. In some ways, the Gospel of John is similar to a law summary that presents arguments about why readers should believe in Jesus Christ; in the middle of the argument are seven signs. Like a court attorney, John, under spiritual inspiration, filtered all the extant evidence i.e., all the signs done by Jesus, and selected his most persuasive argument to prove his claim - these seven signs.

The idea of John's mission in his gospel is an idea that is open to outsiders, which comes from the motivation of love and sees others as needing to be saved (Kok, 2015) and is expressed in a way that transcends boundaries. This agrees with John's symbolic assessment of the state of the world filled with people who are spiritually dead (5:24); sinners enslaved by the devil (8:44). They all need the full life that is found only in Jesus-His mission (John 10:10). Sinners cannot free themselves from existence and spiritual crisis. The only answer to the crisis experienced by sinners "comes only from above" (3:31). God is the God from whom life springs $(1: 1-4)$, and He wants all of His creation to live in peace and be restored to Himself through Jesus Christ (3:16).

\section{CONCLUSION}

The signs that Jesus did in public are part of His earthly ministry which is explicitly identified in the Gospel of John in the language of symbolism, to 
refer to the glory of God shown by Jesus. Jesus declared that He was the only true representative of God on earth.

The seven signs done by Jesus that are recorded in the Gospel of John continue to serve as credible and persuasive witnesses, proving who Jesus really is, proclaiming His glory, and challenging readers (hearers) to believe in Jesus Christ as the only true Son of God. The significance of the signs reveals the glory of God in Jesus to mankind and demands that readers and listeners know, and believe that Jesus is the Messiah, the Son of the living God. Those who believe in Jesus will have eternal life.

Reading the Gospel of John, especially with regard to the seven signs, is still relevant for today's

\section{REFERENCES}

Arndt, W. F., Gingrich, F. W., \& Danker, F. . (2001). A Greek-English Lexicon of the New Testament and Other Early Christian Literature. The University of Chicago Press.

Bauckham, R. (2017). Jesus and The Eyewitnesses: The Gospels as Eyewitness Testimony (Second Edi). William B. Eerdmans Publishing Company.

Blum, E. A. (2010). The Bible Knowledge Commentary: New Testament (R. B. and J. F. W. Zuck (ed.)). Parsons Technology, Quickverse 2010.

Brown, R. E. (1988). The Gospel and Epistles of John: A Consice Commentary. The Liturgical Press.

Carson, D. A. (1991). The Pillar New Testament Commentary: The Gospel According to John (D. A. Carson (ed.)). Apollos.

Carson, D. A., Moo, D. J., \& Morris, L. (2002). An Introduction to the New Testament. OMF Literature Inc.

Constable, T. L. (2020). Notes on John. Sonic Light. Darmadi, D. (2019). Memahami Teologi Yohanes tentang Akhir Zaman. KALUTEROS (Jurnal Teologi Dan Pendidikan Kristen), 1(1), 2133. https://doi.org/10.1234/kaluteros.v1i1.3 believers in two ways: first, although the situation and context presented at the time this Gospel was written was different from today, those who believe in Jesus as Divine will experience eternal life in the present. Second, the Gospel of John is not the only one that reveals the divinity of Jesus Christ through signs and miracles, because there are still the Synoptic Gospels. But the Gospel of John needs to be read by every believer along with the Synoptic Gospels because it emphasizes the main purpose of the signs that Jesus performed - faith in Jesus who is the Messiah and Son of God. Jesus is the revelation of the invisible God, who has existed in human history. Jesus has shown God's eternal and great love for the world.

Estes, D. (2013). The Questions of Jesus in John Logic, Rhetoric and Persuasive Discourse. In Biblical Interpretation Series (Vol. 115). Brill.

Evans, C. A. (2007). Merekayasa Yesus. ANDI OFFSET.

Guthrie, D. (2012). Pengantar Perjanjian Baru Volume 1. Penerbit Momentum.

Harming, H. (2017). Metode Penginjilan Yesus Dalam Injil Yohanes 4:1-42. Evangelikal: Jurnal Teologi Injili Dan Pembinaan Warga Jemaat, $\quad 1(2)$, 162. https://doi.org/10.46445/ejti.v1i2.73

Harris, W. H. (2011). A Biblical Theology of the New Testament (R. B. Zuck. (ed.)). Gandum Mas.

Joihin, J. (2010). Yesus Adalah Roti Kehidupan: Analisis Naratif Yohanes 6:1-71. Jurnal Amanat Agung, 6(2). https://ojs.sttaa.ac.id/index.php/JAA/article/vi ew/135

Keener, C. S. (2012). The Gospel of Jhon A Commentary. Baker Academic.

Keener, C. S. (2014). The IVP Bible background commentary - New Testament (2nd ed.). IVP Academic.

Kok, J. (2015). The plenipotentiary idea as 
Leitmotiv in John's Gospel. In Die Skriflig/In

Luce Verbi, $\quad 49(2), \quad 1-9$. https://doi.org/10.4102/ids.v49i2.1923

Köstenberger, A. J. (2015). Encountering John: Injil dalam Perspektif Sejarah, Sastra dan Teologis. Seminari Alkitab Asia Tenggara.

Lakonawa, P. (2014). Memaknai Simbol-Simbol Religius Injil Yohanes. Jurnal HUMANIORA, $5 \quad$ Nomor $\quad 1, \quad 324-340$. https://doi.org/https://doi.org/10.21512/huma niora.v5i1.3031

Merwe, D. G. van der. (2019). The divinity of Jesus in the Gospel of John: The 'lived experiences' it fostered when the text was read. HTS Teologiese Studies/Theological Studies, 75 (1), 1-13. https://doi.org/https://doi.org/ 10.4102/hts.v75i1.5411

Morris, L. (2014). Teologi Perjanjian Baru. Gandum Mas.

Oet, S. (2016). Keilahian Yesus Menurut Injil Yohanes. Manna Rafflesia, 2(2), 135-147. https://doi.org/10.38091/man_raf.v2i2.61

Reinhartz, E. A. (1999). SEMEIA 85 God the Father in the Gospel of John. The Society of Biblical Literature.

Schreiner, T. R. (2015). New Testament Theology: Memuliakan Allah dalam Kristus. ANDI OFFSET.

Sihombing, W. F., Tambunan, P., \& Manurung, A. M. (2021). Yesus Hamba TUHAN Yang Dipilih (Penggenapan Yesaya 42:1-4 dalam
Matius 12:15b-21). Jurnal Teologi Cultivation, 5(1), 129-143. https://doi.org/10.46965/jtc.v5i1.649

Simanjuntak, R. M. (2019). Kristologi dalam Injil Yohanes. Jurnal Teruna Bhakti, 1(2), 75-86. https://doi.org/10.47131/jtb.v1i2.15

Stibbe, M. W. G. (2001). John's Gospel. Routledge. Subagyo, A. B. (2004). Pengantar Riset Kuantitatif dan Kualitatif. Kalam Hidup.

Tafaib, G. (2014). Paham Eskatologi dalam Injil Yohanes dan Makna Temporalnya. Jurnal Orientasi Baru, 23(2), 115-126. https://ejournal.usd.ac.id/index.php/job/article/view/1 129

Tarigan, B. (2019). Konsep Doa Yesus Kristus Menurut Yohanes 17:1-26. Kerugma: Jurnal Teologi Dan Pendidikan Agama Kristen, 1(2), 110-121. http://www.sttiimedan.ac.id/ejournal/index.php/kerugma/article/view/9

Tenney, M. C. (2010). Survei Perjanjian Baru. Gandum Mas.

Wenham, D. (2003). John's Gospel: Good News for Today. Religious and Theological Students Fellowship.

Zuiddam, B. (2016). Parallelisms and revelatory concepts of the Johannine Prologue in GrecoRoman context. HTS Teologiese Studies/Theological Studies, Vol. 72, N, 1-11. https://doi.org/a3115. http://dx.doi. org/10.4102/hts.72i3.3115 